\section{The Productivity Commission and industrial relations reform}

\section{David Peetz}

Griffith University, Australia
The Economic and Labour Relations Review 2016, Vol. 27(2) 164-180 (C) The Author(s) 2016 Reprints and permissions: sagepub.co.uk/journalsPermissions.nav DOI: $10.1177 / 10353046 / 6649305$ elrr.sagepub.com

(\$SAGE

\begin{abstract}
This article considers the political economy of the Productivity Commission in industrial relations reform; in particular, its review of the industrial relations framework foreshadowed in 2013 and conducted in 2015. Following a history of the establishment of the Productivity Commission and its predecessor agencies, it argues that the concepts of third-party independence and third-party endorsement are important for understanding the role of the Productivity Commission. A review of the politics of industrial relations reform leads into the central analysis of the political economy of the Productivity Commission's 2015 inquiry into the Australian workplace relations framework. The concepts of third-party independence and endorsement are applied in analysing some of the inquiry's key recommendations. The conclusion discusses several difficulties in the political economy of the Productivity Commission and its relationships to government and, indeed, to evidence, when the latter contradicted its mainly liberal market stance.
\end{abstract}

JEL Codes: D73, HI I, J5 I, J53, J58

\title{
Keywords
}

Construction industry employment relations, employment relations reform, independent third party policy agencies, industrial relations framework, market liberalism, penalty rates, Productivity Commission, third-party endorsement

\section{Historical background}

The origins of the Productivity Commission (PC) go back to the Tariff Board, established in the 1920s to recommend on the levels of tariffs and quotas applicable to imports. Traditionally housed within the Trade or Secondary Industry portfolio, the Tariff Board

\section{Corresponding author:}

David Peetz, Department of Employment Relations and Human Resources, Griffith University, Kessels Road, Nathan, QLD 4I I I, Australia.

Email: d.peetz@griffith.edu.au 
was typically accountable to a Country Party minister (most famously, Deputy Prime Minister 'Black Jack' McEwen) in the days when the minister and his department were strongly protectionist and were mostly captured by the industries they oversaw. The Whitlam Labor government, coming to office after 23 years in opposition, was deeply (and mutually) suspicious of its bureaucratic advisors. Whitlam wanted to challenge traditional protectionism, expand the bureaucratic perspective from manufacturing to all industries and establish a transparent process of expert and public inquiries on industry assistance (Lloyd and Reid, 1974). His government cut tariffs by 25\% in July 1973 (Hocking, 2012), revalued (upwards) the Australian dollar and replaced the Tariff Board with a new agency, the Industries Assistance Commission (IAC), staffed with economists more inclined to cutting than maintaining tariffs (Lloyd and Reid, 1974).

The IAC quickly established a reputation as a liberal market institution. Its recommendations, usually for reduced tariffs, were supported by Treasury and (after it was split from Treasury in 1976 by the Fraser government) the Department of Finance, but they often lacked support from the Industry department. Both major political parties were divided on tariff issues through the 1970s and early 1980s, but on balance, the Fraser Liberal-National Party Coalition government remained somewhat protectionist, although in economic policy circles a strongly market-based philosophy (referred to as 'monetarism', after a model devised by Milton Friedman) was taking hold.

In 1983, a new Labor government, with Bob Hawke as Prime Minister, came to power, having just negotiated a prices and incomes Accord with the Australian Council of Trade Unions. The Accord represented a different and more interventionist way of conceiving economic problems, and so there was a battle for ideas in the mid 1980s between this approach and the new liberal market orthodoxy represented by Treasury, the IAC and a growing band of senior officials in other departments. Whereas the Accord envisaged the newly established Economic Planning and Advisory Commission (EPAC) as an independently thinking long-term economic planning body, the new Treasurer, under departmental advice, established it in such a way that it became another orthodox source of (longer term) economic advice similar to that coming from Treasury. In the end, in the grand contest of ideas within government, the market-liberal view prevailed. It received impetus from the new Treasurer's lack of prior economics training, the Hawke government's wish not to repeat the well-documented mistakes of the Whitlam government in its relations with Treasury (Freudenberg, 1977; Weller and Cutt, 1976), the rise of financial markets following the December 1983 financial deregulation and the currency and terms of trade crises of 1985-1986. This market-oriented philosophy came to characterise policy-making through the rest of the Labor period, albeit tempered substantially by union pressure, political considerations and the social justice objectives still held by government members.

When the Howard Liberal-National Party government came to office in 1996, it sought savings, including by merging or abolishing agencies. It merged the Industry Commission (renamed from the IAC in 1989), EPAC and the Bureau of Industry Economics into the new PC, but with the former Industry Commission staff clearly dominant. Importantly, the PC's remit was wider than the IAC's, now encompassing a broad range of policy matters. During the Howard government years, the PC's publications, when touching on industrial relations issues, typically treated trade unions and industrial 
laws as market imperfections and highlighted what it saw as inefficiencies arising from these institutions (Business Spectator, 2013).

In 2007, the Howard government was defeated at an election largely fought on industrial relations issues. The new Rudd and Gillard Labor governments were hesitant to challenge existing policy institutions and did not seek to fundamentally alter the PC. They used it to seek independent advice on some issues, most famously on paid parental leave. The PC in turn adapted to the need to be relevant to a social democratic government with broader concerns; nevertheless, it still applied a decidedly market liberal approach to solving policy problems (Green and Toner, 2014). At times (e.g. on executive remuneration), the Labor government would refer a matter to the PC in the wellreasoned hope that the $\mathrm{PC}$ would kill off more interventionist and controversial ideas (Productivity Commission (PC), 2009). After the Abbott government came to office in 2013, the PC had less need to be sensitive to social considerations. Importantly, although, it is a state agency with its own logic, including that of its own survival. For these purposes, the issue of the appearance of independence is critical.

\section{Third-party independence and third-party endorsement}

On one hand, the PC cannot ignore the wishes of any current government; on the other, it cannot afford to lose altogether the shield of third-party independence on which it relies to survive future changes of government. The history of the appearance of independence goes back to the early days of the IAC. Like the IAC, the PC holds inquiries, invites submissions and publishes issues papers and draft as well as final reports, reinforcing its self-image as an independent agency and making it quite unusual amongst federal government bodies. It sees its deliberations as evidence based.

This perception creates tensions when the evidence directly conflicts the economic models upon which it would appear the philosophy of the majority of staff is based. Sometimes the result is an acceptance of the evidence as contradicting commonly held liberal market beliefs, even on industrial relations. For example, on the question of the impact on productivity of the Building Industry Taskforce (BIT), created by Minister Abbott, and the Australian Building and Construction Commission (ABCC), ${ }^{1}$ the PC reflected that 'it cannot be maintained that the data show - even in an indicative sense - that aggregate productivity improved because of the BIT/ABCC' (PC, 2014: 786). It added, however, the unquantified caveat that it 'still considers that the BIT/ABCC had positive effects in its heyday ... [b]ut its impact is likely to have been masked' (PC, 2014). At other times (an example is provided below), the PC reworked the evidence to fit in with its model. The explanation for these different responses is uncertain, but may relate to personnel differences within the organisation - perhaps, some staff are more committed to evidence and some to a consistent economic philosophy.

One reason to be wary of the concept of independence when applied here is the logic of bureaucratic survival. Just as one Liberal-National Party government abolished the Industry Commission and created the PC, so another could easily abolish the PC (or 'merge' it within, say, Treasury). Another reason relates to governments' reasons for using arm's length agencies. A well-used quotation from the satirical series Yes Minister is 'never set up an enquiry unless you know in advance what its findings 
will be' (Lynn and Jay, 2011: 453): governments may refer matters to the PC in the expectation, based on its economic philosophy, that it will provide the answer they seek. Thus, whereas the IAC was originally set up to play a role of third-party independence in providing advice, some of the inquiries sent to the PC by government have instead been for the purpose of securing third-party endorsement.

Governments and lobby groups go to considerable lengths to obtain third-party endorsements, as a means of securing legitimacy for their policies. Marketers refer to the 'astonishing power' of third-party endorsements for anyone marketing a product (Walker and Burgin, 2015). They offer 'campaigns to obtain third party endorsement' in order to 'build trust through third-party influencers' (Ivy Worldwide, 2016).

Governments and lobby groups use a variety of institutional mechanisms to obtain such third-party endorsements. Often, it is simply a matter of freely provided support from a sympathetic person or organisation. Sometimes, though, it must be paid for. A common method is through consultancy reports, especially where some form of modelling is required to show a desired economic outcome. Such reports, according to one observer, are

$\ldots$ an exercise in dazzling the punters with pseudo-science. Anyone can make claims about the economic benefits or costs of a particular policy, but those claims gain an air of authority and false precision when they come out of an econometrician's black box ... The commissioning of special reports, the use of words such as 'independent' and 'respected', and the quoting of 'point estimates' rather than ranges are intended to create an air of certainty and God's truth revealed ... The results from models are based on a mountain of assumptions - assumptions that are built into the model's equations and further assumptions that are fed into the model and every assumption is open to debate. (Gittins, 2007)

Nevertheless, media coverage of consultancy reports is usually uncritical, and so they are used to give the aura of third-party endorsement. Other sources of third-party endorsement include seemingly independent 'think tanks', typically financed by corporate interests or other lobby groups (Murray, 2006: 147-175), and Royal Commissions, which 'attract public confidence as being impartial, non-political and independent' (Ransley, 2015). The PC's economic modelling capacity gives it particular importance in providing third-party endorsements for particular policy actions. However, it is not always used for this purpose - the Gillard government's use of it to propose a paid parental leave scheme is one example. Nor can it be relied upon to always give a politically 'correct' (also, ironically, PC) response. An example was its assessment of productivity growth in the construction sector, mentioned above, leading to Prime Minister Turnbull publicly preferring the discredited findings of an economic consultancy over those of the PC on that issue on national television (Allan et al., 2010; Turnbull, 2016).

The increasingly important function of the $\mathrm{PC}$ in providing third-party endorsement is important to understanding its role in industrial relations.

\section{The politics of industrial relations and the PC}

Following the defeat of the Howard government, including the loss of the Prime Minister's seat, at the 2007 election, the Liberal-National Coalition, in opposition, was 
keen to distance itself from the politically damaging 2005 'WorkChoices' industrial relations legislation. This was seen as costing it the election (Crowe, 2007; Maley, 2007; Morris, 2007), an assessment endorsed by statistical analysis (Spies-Butcher and Wilson, 2007). Opposition Leader Tony Abbott referred in 2010 to WorkChoices being 'dead, buried and cremated' (Curtis, 2010). Yet industrial relations deregulation was 'an article of faith' for Coalition members (Howard in Hudson, 2005) - an area of strong ideological conviction - it had been the issue on which surveys show the greatest difference between Coalition and Labor party candidates (Taft, 1998). So the Coalition needed a new public approach to industrial relations.

The Coalition's 2015-2016 industrial relations strategy appeared to be inspired by its earlier, successful approach to the introduction of a goods and services tax (GST). Prior to the 1996 election, following a surprise 1993 election loss on the issue, Opposition Leader Howard had pledged to 'never, ever' introduce a GST, 'it's dead' (quoted in ABC (Australian Broadcasting Commission), 2015). Yet after winning a large majority in 1996, his new Government promised to introduce the tax after the 1998 election. Despite a swing against it, the Coalition won the 1998 election and was able to enact this major policy change. Repeating this strategy would require a nondescript industrial relations policy in the lead-up to the 2013 election, 'keeping industrial relations off the front pages' (Kenny and Lucas, 2013) consistent with the 'dead, buried and cremated' remark, followed by a major shift in policy before the 2016 election. The latter would require two things: a policy package more attractive than, but as effective as, WorkChoices and a strong rationale for the change of heart. The new package would place less emphasis than in 1996-2006 on directly reducing employee entitlements (achieved in WorkChoices through such mechanisms as requirements to offer individual Australian Workplace Agreements over-riding collective agreements and removal of unfair dismissal protections). Instead, it would rely more on directly attacking trade unions, whose power ultimately enabled employees to protect and boost their pay and conditions - building on the belief that voters had little faith in union leaders' honesty (Roy Morgan Research, 2014), but perhaps underplaying the popular acceptance of unions' role in society (Peetz, 2002, 2010).

The rationale for the change of approach would come from two major reports endorsing such a policy: a Royal Commission into Trade Union Governance and Corruption and a PC inquiry into the workplace relations framework, dealing with pay and conditions matters. The latter was promised in May 2013, 4 months before the 2013 election (Liberal Party of Australia and National Party, 2013), and the former was announced several months after it. Although industrial relations have been a long-standing matter of policy contention, it had never been referred in its own right to the $\mathrm{PC}$, as the parties' positions were well established, and obtaining an independent opinion from the PC, with its well-understood philosophy, would serve no purpose. Now, however, the PC could serve a concrete and important purpose to provide third-party endorsement for the policies that the Coalition preferred to enact.

A difficulty, however, with this method of securing third-party endorsement is that a government is unable to be certain of the content of the report before it is provided and, especially with the PC, is unable to control the timing of reports. Moreover, once the report is commissioned, a change in political circumstances is hard to accommodate. 
In the unlikely event of a consultant's report being unhelpful, it can simply be suppressed, but this option is not available with a report from the PC.

So it was that changing political circumstances greatly complicated the PC industrial relations report. Instead of enjoying a long 'honeymoon' period in opinion polls, as Howard and other new governments had experienced - a precondition for advancing a radical policy before its first re-election campaign - the new Abbott government soon found itself trailing in the opinion polls. Despite the leaking of a draft in March 2014, announcement of the terms of reference for the PC industrial relations inquiry was delayed until December 2014, over a year after the 2013 election. The PC released 'issues papers' in the following month (Abetz and Hockey, 2014; Massola, 2014b; Productivity Commission, 2015b). Although some senior Coalition politicians believed industrial relations had been 'neutralised' as a political issue and were willing to speak publicly on the issue (Massola, 2014a; Taylor, 2015), without a strong polling lead a radical industrial relations policy would be dangerous. In late 2015, Abbott was deposed and replaced as Prime Minister by Malcolm Turnbull. This change led to a substantial but seemingly temporary rise in popularity of the government and by the early months of 2016, it was unclear how the government would respond to the recommendations of the PC inquiry, which had been handed down in November 2015.

\section{The PC inquiry into the workplace relations framework}

The PC's 'issues papers' suggested that the PC planned a very broad-ranging approach to the topic, consistent with ultimately making what conservative commentators hailed as potential 'once in a generation' recommendations (The Australian, 2015). The PC challenged some issues - such as the distinction between competition law and industrial relations law - that had been fundamental to the operations of industrial relations in Australia for a century and to the concept, underpinning labour law, of achieving some sort of balance of power in the workplace. The language of the review suggested that it was a review only of employer issues of productivity and flexibility, with no counterbalancing attention to employee issues of equity and justice. In the issues papers, there were 40 mentions of 'flexibility' and 50 of 'productivity', but only three of 'equity', while 'justice' was only mentioned in other articles' titles. 'Penalty rates', 'dismissal', 'minimum wages' and 'awards' - all sources of employer complaint - received 45, 50, 142 and 123 mentions respectively; 'women' received three (mostly historical), 'gender' another three, 'inequality' two and 'poverty' one.

The final PC industrial relations report, though over 1000 pages long, was less ambitious. It also showed signs of some of those apparent internal tensions mentioned earlier. Some parts of the report seemed reflective of a quite purist market liberal model, sometimes even torturing data to match the model; while others seemed more cognisant of industrial relations reality.

The main focus of publicity from the PC report was on its recommendation to cut Sunday wage premiums - 'penalty rates' - for retail and hospitality workers. Surprisingly, the PC did not recommend abolition of all penalty rates but consistent with the newly incremental approach adopted by employers in the 2015 review of modern awards by the industrial tribunal, the Fair Work Commission (FWC), it instead focussed on reducing 
Sunday penalty rates. To some outside observers, this specialised focus seemed almost arcane and hardly a fundamental challenge to industrial regulation. But it reflected two things: the change in the political climate on industrial relations in light of the poor popularity of the Abbott government and the strategic importance of penalty rates in employers' labour cost agendas. On the most recent previous occasion, when employers had opportunity to make major savings in labour costs - through the availability of Australian Workplace Agreements (AWAs) without an underpinning 'no disadvantage' test in the WorkChoices years - the main way in which employers had achieved cuts in labour costs was through reductions in penalty rates for night and weekend work and in overtime pay (Peetz and Preston, 2009). With the lessons of the 2007 election remembered, there was now little prospect of the award 'safety net' of penalty rates being sidelined through AWAs. Instead, the focus would be on reducing the safety net itself, by directly reducing penalty rates in Australia's system of 122 modern awards, established and periodically reviewed by the FWC, the body that formally sets award rates of pay. The government's willingness to legislate directly on penalty rates might be weak, but employers could more directly aim to achieve their goal through the review of penalty rates in modern awards in the retail and hospitality sectors being undertaken by the FWC. This was the great political advantage of focusing on penalty rates: the government could set the scene and commission an appropriate set of findings from the PC, without having to take political blame itself.

So it was that, several months after the PC report was handed down, the employer bodies in the penalty rates case before the FWC sought permission, after cross-examination of experts had been completed, to have the PC report 'admitted into evidence', without the opportunity for its authors to be cross-examined. This bid was strongly opposed by union representatives. The FWC declined to admit the PC report in exactly the form sought by employers, but nonetheless admitted it 'as part of the common evidence before the Full Bench', allowing parties to address in their final submissions (long after the expert evidence had been finalised and tested) the 'weight to be attributed to it' ((2016) FWCFB 965). The outcome of the case before the FWC was unknown at the time of writing, and one should not exaggerate the role of evidence in determining outcomes. As influential as the thousands of pages of exhibits, testimony and argument may be, precedent may be even more powerful - in particular, a FWC decision in 2014 to cut Sunday penalty rates for casual restaurant employees ((2014) FWCFB 1996). If the FWC decided to cut Sunday penalty rates in retailing, the PC report might provide an important third-party endorsement for that decision.

In the rest of this section, we consider in detail some of the PC recommendations, but with particular emphasis on its prognostications regarding penalty rates.

\section{Penalty rates}

The great majority of workers who would lose wages from the PC recommendations with wage cuts of $17 \%-37.5 \%$, as estimated by the commission, for Sunday work - were non-unionists. They have weak bargaining power - notwithstanding the PC's statement that 'employers in such industries are not likely to have the same level of bargaining power over their employees as in many other industries'. The Fair Work Ombudsman's 
(FWO) (2014) more experience-based view was that that parts of this sector have 'high non-compliance risk and are employers of vulnerable workers' (p. 34).

The PC espoused the opinion that 'businesses would not be the beneficiaries of deregulated penalty rates' - a comment at odds with the long 'campaign' waged by business bodies to cut penalty rates there, not just on Sundays (Desloires and Dunckley, 2015; NSW Business Chamber, 2013; Price, 2015; Tran, 2015) and with the fact that the PC did not propose 'deregulated penalty rates' (perhaps a function of that internal tension mentioned earlier). Among consumers, considered by the commission as the beneficiaries, $81 \%$ opposed the removal of penalty rates (Essential Media Communications (EMC), 2015). Explicitly omitted from the PC's agenda to cut penalty rates (again, consistent with the employer agenda) were essential services such as nursing, policy and fire services and even continuous production manufacturing. Workers in most of these areas were more highly unionised and would put up much more visible resistance if their penalty rates were challenged (Phillips, 2014). Some observers plausibly wondered if that was the reason they were excluded, but had no doubt that a precedent set in retail and hospitality would eventually set the tone for the rest of the workforce (Lyons, 2015). The Business Council of Australia proposed to 'start with the Productivity Commission's proposal and then go further' (Westacott, 2015).

An example of the tension between evidence and a market liberal economic philosophy occurred when the PC discussed the evidence on penalty rates. On one hand, it recognised that there were 'several deficiencies', identified by the PC (2015c) and other economists, in the 'evidence for policy change' presented by the main witness for the employers and conceded that 'robust evidence' in favour of lower penalty rates was 'hard to find' (p. 490). This was for good reason: there was a substantial body of material presented to the FWC and available to the PC indicating that Sunday penalty rates did not reduce employment (Borland, 2015; Quiggin, 2015; Yu, 2015). On the other hand, rather than accepting this material as evidence against reducing working conditions, the PC $(2015 \mathrm{c})$ report devoted a whole section to arguing that the 'burden of proof' should be on the 'proponents of the current high rates' (pp. 461,489-492). It insisted there 'will be positive and beneficial' effects on employment (p. 462, emphasis added). Of course, it is in the nature of statistical hypothesis testing that a hypotheses can never be absolutely proven, it can only be accepted or rejected. Faced with (and accepting) evidence that ran counter to its philosophy, the PC sought to overturn statistical conventions and assert that anyone who disagreed with its philosophy had to prove that the PC was wrong. It was a far cry from the Report's promise that 'careful judgements' about the 'probabilities' of certain policy effects were required (p. 202). It was as if one part of the organisation had found that the evidence went one way, but another part decided that, if the evidence is not consistent with our philosophy, it is necessary to redefine that evidence as not meeting a new burden of proof.

The PC also claimed that community attitudes on penalty rates for Sundays had changed, but presented no attitudinal evidence on this. It argued that Sundays were no worse for workers than Saturdays, although the authors of the survey evidence that the PC cited, from the Centre for Work + Life (CWL), concluded, 'Those who work on Saturday and particularly Sunday have worse work life interference - an issue that is relevant to the current debate about penalty rates in Australia' (Skinner and Pocock, 2014: 1, emphasis 
added). CWL researchers were rightly annoyed that the $\mathrm{PC}$ had misrepresented the data (2016, personal communication; see also Pocock, this volume). The PC observed that 'the worst social disabilities arise from evening work' and that evening rates were much lower than weekend rates, but it made no recommendation to increase evening rates. This surprised no-one.

\section{Enterprise contracts}

The PC recommended the introduction of 'enterprise contracts'. These proposed contracts combined key features of two previously abandoned instruments. One was 'employer greenfield agreements' (EGAs), which existed only under the WorkChoices legislation in force between 2005 and 2009. They enabled an employer to 'make an agreement' with itself on the conditions that would apply to new employees - but only in a new establishment, whereas 'enterprise contracts' would apply in any establishment of any size and age. The PC said its recommendation on 'enterprise contracts' would 'go a long way in allowing enterprises to negotiate with individuals without union representation if that is their wish'. Unfortunately, it would not be a 'negotiation because the employers would be able to establish an enterprise contract "without having to negotiate" with anyone. Indeed, it could be offered "to all prospective employees as a condition of employment'. The enterprise contract would not be subject to the existing 'better off overall test' that currently applied to enterprise agreements and individual flexibility arrangements. Instead, it would be tested against a weaker 'no disadvantage' test. Under WorkChoices, EGAs had led to frequent cuts in penalty rates and other conditions (Gahan, 2007).

The second instrument inspiring 'enterprise contracts' was that of the individual contracts known as Australian Workplace Agreements (AWAs). Under WorkChoices, AWAs could be offered as a condition of employment. Even when they were subject to a 'no disadvantage' test (under the Workplace Relations Act 1996 before it was amended by the WorkChoices legislation), AWAs were shown to lead to lower pay and conditions (and/or to be used for union avoidance) (Peetz, 2006; Peetz and Preston, 2009).

As with AWAs and EGAs, enterprise contracts would most clearly affect non-union workers by reducing conditions but also facilitating union avoidance. The PC also proposed (although this was not clear in the report) that employees be unable to recover any underpayments achieved through such contracts (Harris, cited in Hannon, 2015). This proposed provision would especially disadvantage non-union workers and open the system to the extensive abuse experienced by migrant workers, especially that already welldocumented in retailing, hospitality and agriculture (Ferguson et al., 2016).

\section{Individual flexibility arrangements and some other changes}

The PC proposed that the period of notice for cancelling an unsatisfactory 'individual flexibility agreement' be multiplied by up to eight times. The Fair Work Act 2009 had abolished AWAs and instead required that all awards include a standard 'flexibility term'. This provision, among other things, enabled the establishment of 'Individual Flexibility Arrangements' (IFAs) between individual employees and an employer. Unlike the 
former AWAs (which were scrutinised by the Office of the Employment Advocate), IFAs are not routinely scrutinised by any agency. They are held in the payroll office of the employer. If the FWO inspects the wage records of an employer and an IFA is below standard, then the employer is in breach of the award. This happens only if an employer is found out: either the employee has to know to make a complaint (and if they knew they were being underpaid, they might not have signed the IFA) or the FWO has to know to conduct an inspection of that workplace. In 2012, three quarters of IFAs were used to formalise what were previously informal and, by implication, illegal practices (Fair Work Commission, 2012). Most IFAs were initiated by employers, not employees, so the flexibility is predominantly for the benefit, in the first instance, of the employer. Many employees on IFAs were required to sign as a condition of getting or keeping their job - this was the case for half the employers who used IFAs (Fair Work Commission, 2012). This circumstance appears to indicate a frequent breach of section 344[c] of the Fair Work Act. In the context of the problems, IFAs already present regarding compliance, multiplying eightfold the period of notice for cancelling an unsatisfactory one would exacerbate exploitation of vulnerable workers.

There were a number of other recommendations in the PC report, too numerous to detail here. For example, the PC proposed changing unfair dismissal laws to enable the FWC to ignore breaches of proper procedure by employers. Again, this would have the biggest impact in non-union firms, which are less likely to have formal systems and procedures in any case (Verma, 2005). Many of the other PC recommendations, in areas such as industrial action, would reduce the bargaining power of unions.

\section{Market versus Stalinist neoliberalism}

Notwithstanding the recommendations outlined above, many of the findings and recommendations were not what the Coalition government would probably have been seeking - at least, not at the time it decided to promise the PC review. For example, the PC could find no evidence that there would be productivity gains from major changes to the industrial relations system or even from reducing the level of industrial conflict. It found 'little evidence that unfair dismissal laws are a major obstacle to hiring' (PC, 2015c: 30). It observed that 'Australia has one of the more light-handed suites of arrangements' for protecting employees from unfair dismissal (PC, 2015c: 29), that the level of strikes is low, the system is largely working, and even (a statement unusual for the PC) that "without regulation ... employees are likely to have much less bargaining power than employers, with adverse outcomes for their wages and conditions' (p. 2). While a fair assessment of the available evidence, some of these observations read as if they were not written by the same hands that wrote about the absence of any long-term impact of penalty rates on profits or the merits of enterprise contracts. The PC also favoured implementing some of the remaining recommendations of the 2012 review into the Fair Work Act (McCallum et al., 2012).

There were also examples of how available evidence, and a market philosophy, combined to weaken the case for greater intervention against workers. Detailed prescriptions on the procedures to be followed in applications for secret ballots and 'legal' industrial action were one instance. A market (and democratic) solution would require 
unions hold secret ballots before undertaking industrial action, but would leave implementation to the parties (unions) to work out. Yet, the WorkChoices legislation imposed 26 pages of procedural requirements designed to provide detailed notice to employers of any action and numerous opportunities for employer interventions to pre-empt it. The Labor government, under pressure from employer organisations, left these mostly unchanged in the Fair Work Act. Yet, the PC report questioned the complexity of secret ballot procedures supported by both parties. It also recommended the bar be lowered for identifying 'sham contracting' arrangements by employers and argued for improved protections for migrant workers.

The PC (2015a) also questioned, in its draft report, prohibitions on 'pattern bargaining' when such bargaining may lead to 'low transaction cost agreements that parties genuinely consent to' (p. 53). Its final report observed that 'a blanket prohibition on pattern bargaining would have unintended and undesirable consequences' (PC, 2015c: 645, although a true market liberal solution would impose no restrictions on pattern bargaining by unions, especially given that employers routinely engage in pattern bargaining (Ling and Waterhouse, 2009; McCrystal, 2006). The final report also recommended that Parliament abandon a Bill, at the time before the Senate, that sought to involve the FWC in assessing the 'excessiveness' of union claims, as 'undermining the decentralised and enterprise-oriented focus underpinning the WR framework' (PC, 2015c: 882). That Bill also mandated, in enterprise agreements, 'productivity clauses' that the PC saw as 'likely to have perverse effects' (PC, 2015c: 694).

Such challenges arise because of the type of institution that the PC is: 'a market liberal body that mostly searches for a close approximation to market solutions to any problem it is asked to address'. In some ways, the workplace policies of the Howard Coalition government, which provided key ministers (such as Ministers Abetz and Hockey) for the Abbott government, were not so much representative of market liberalism as 'Stalinist neo-liberalism' (Peetz and Bailey, 2011). While in certain aspects that government sought to expose employees to unconstrained market forces, it also sought to intervene in the employment relationship in great detail, prompting criticism from the conservative HR Nicholls Society that its policies were 'the old Soviet system of command and control, where every economic decision has to go back to some central authority' (Evans, reported in Carbonell, 2006). The preferences of the Abbott and Turnbull governments appeared similar, although they have been understandably less adventurous.

\section{Conclusion: Contradictions and the PC}

The PC is a market liberal institution whose recommendations on industrial relations would disadvantage workers, by reducing their income and power and favour corporations. Most prominently, that is the case in relation to enterprise contracts and cutting penalty rates for Sunday work, but it also applies to recommendations in such areas as individual flexibility arrangements, unfair dismissals and industrial action. It appears to have originally been used by the Liberal-National Party Coalition government to obtain ex ante third-party endorsement for a more radical industrial relations agenda in the leadup to the 2016 election. If so, that strategy was thrown into doubt by the poor polling of the Coalition government in its first term in office, highlighting one of the difficulties of 
seeking to obtain ex ante third-party endorsement in a potentially changing political environment. The great advantage and disadvantage of a PC inquiry concerned its separation from the government. The government needed a seemingly 'independent' rationale for radical industrial relations change. However, this independence took a highly contentious and potentially embarrassing issue out of the control of the government. The experience of the PC on industrial relations also highlights a number of difficulties arising from a series of contradictions.

The first contradiction is that between a government seeking third-party endorsement and an agency seeking to reproduce itself and its ideology by use of what it sees as evidence. The findings that the system was largely working, that there were no major productivity gains to be had from systemic change, that dispute levels were low, that unfair dismissal laws were lax by international standards and unlikely to be an obstacle to hiring, and that without regulation, employees would have much less bargaining power than employers were all based on evidence and contradicted many of the ideas upon which the rationale for WorkChoices was based. They also contradicted many of the prior beliefs of those in the Liberal Party. Whether they were what the government wanted it to say at the time is another matter and impossible to ascertain, but even if they were, they make it difficult for radical reform to occur in the near future without a new review and a change of heart by the PC.

The second, related contradiction is that between a government wanting a form of 'Stalinist neoliberalism' and an agency more committed to market liberalism. The PC's recommendation for more liberal laws on secret ballots was an illustration - the PC wanting less restrictions than were imposed both by Coalition and by Labor governments. The fact that Labor had endorsed importing the WorkChoices provisions with minor changes into the Fair Work Act also illustrated how sensitive the Labor government had become to employer criticism and how much of the 'Stalinist neoliberalism' of WorkChoices had been retained in the Fair Work Act.

The third contradiction is that between what the evidence says and what the philosophy demands. The way in which some parts of the PC Report look to be written by less ideologically committed hands than other parts illustrates this. Related to this third contradiction, then, might be unobserved contradictions within the agency between those parts wishing to examine the evidence carefully and those wishing to focus on reproducing the philosophy. Perhaps, the starkest illustration of this contradiction between evidence and philosophy comes in the discussion of penalty rates. One hand writes of how deregulating penalty rates would produce gains for consumers, not profits, while another hand recommends against deregulation and instead for reduction of Sunday penalties. One hand writes of how cutting penalty rates will increase employment, while the other writes of the lack of evidence in support of such a proposition. To attempt to resolve these contradiction, the PC ties itself in knots arguing for a new statistical convention, that the 'burden of proof' against change lies on those supporting existing policy to prove that a cut in penalty rates would not lead to increased employment.

In the end, the PC's report on the workplace relations framework was not as philosophically purist as many were expecting. To what extent this was because of the apparent internal contradictions within the PC, the conflict arising from its being a market-based institution working for an actively interventionist government or because it possessed 
more finely tuned political antennae than many expected - by the time the draft report came down, in August 2015, few in the Abbott government would have wanted a radical industrial relations policy anyway - is difficult to assess. Either way, at the time of writing, it appeared unlikely that all of its recommendations would be accepted by the government. It is, of course, dangerous for a writer to make predictions about things that may be known by the time the article is published, but at time of writing, it seemed that the more vulnerable recommendations would be either those that were politically too dangerous (such as 'enterprise contracts') or those that were not interventionist enough (e.g. on secret ballots, where neither party was willing to endorse a more market-based approach). On weekend penalty rates, however, the government could afford to be relatively silent. The main body dealing with this issue was the FWC. An avowedly interventionist government might pass laws regarding the handling of penalty rate cases, but a more politically sensitive one would leave the matter with the FWC. Between them, the $\mathrm{PC}$ and the FWC could facilitate both third-party endorsement and third-party blame.

\section{Acknowledgements}

The author thanks anonymous referees for their advice.

\section{Funding}

The author received no financial support for the research, authorship and/or publication of this article.

\section{Note}

1. The Building Industry Taskforce (BIT) was established in 2002 and succeeded in 2005 by the Australian Building and Construction Commission (ABCC) which had wide powers to monitor, investigate and enforce alleged breaches of federal industrial law within the building industry. Opposition to its powers to coerce evidence and enter and search premises led to its 2012 replacement under Labor by a body called Fair Work Building and Construction. Contest over The Liberal-National government's legislative efforts to reintroduce the ABCC were used in 2016 as a potential early election 'trigger' (Hannan, 2016).

\section{References}

Abetz E and Hockey J (2014) Productivity Commission review of the workplace relations framework. Press Release, 10 December. Available at: https://ministers.employment.gov.au/abetz/ productivity-commission-review-workplace-relations-framework (accessed 12 April 2016).

Allan C, Dungan A and Peetz D (2010) 'Anomalies', damned 'anomalies' and statistics: construction industry productivity in Australia. Journal of Industrial Relations 52(1): 61-79.

Australian Broadcasting Commission (ABC) (2015) GST debate: will they? Won't they? Who's said what about the goods and services tax. ABC News Online, 21 July. Available at: http:// www.abc.net.au/news/2015-07-21/gst-promises-timeline-who-said-what-abbott-howardhockey-hewson/5463652 (accessed 8 April 2016).

Borland J (2015) Report to the Fair Work Commission Examining the Report by Professor Lewis on Penalty Rates and the Retail, Cafe and Restaurant, and Hairdressing and Beauty Services Expert Report. Melbourne, VIC, Australia: University of Melbourne. Available at: https:// www.fwc.gov.au/documents/sites/awardsmodernfouryr/AM2014305-UV-Borland-040915. pdf (accessed 8 April 2016). 
Business Spectator (2013) Productivity Commission, unions at odds over review of IR laws. Productivity Spectator, 25 June. Available at: http://www.businessspectator.com.au/ news/2013/6/25/productivity/productivity-commission-unions-odds-over-review-ir-laws (accessed 8 April 2016).

Carbonell R (2006) Debate continues as IR laws take effect. Lateline, 27 March. Available at: http://www.abc.net.au/lateline/content/2006/s1602129.htm (accessed 8 April 2016).

Crowe D (2007) WorkChoices does the job for labor. Australian Financial Review, 26 November, p. 5. Curtis L (2010) Abbott sends mixed WorkChoices messages. ABC News Online, 19 July. Available at: http://www.abc.net.au/news/2010-07-19/abbott-sends-mixed-workchoicesmessages/911064 (accessed 25 March 2016)

Desloires V and Dunckley M (2015) Employers step up efforts to get rid of penalty rates. Sydney Morning Herald, 3 January. Available at: http://www.smh.com.au/business/employersstep-up-efforts-to-get-rid-of-penalty-rates-20150102\&ndash;12gylv.html-ixzz43vB0pyx9 (accessed 1 April 2016).

Essential Media Communications (EMC) (2015) Penalty rates. Essential Report, 28 July. Available at: http://www.essentialvision.com.au/penalty-rates-3 (accessed 1 April 2016).

Fair Work Commission (2012) General Manager's Report into the Extent to Which Individual Flexibility Arrangements Are Agreed to and the Content of Those Arrangements. Melbourne, VIC, Australia: Fair Work Commission. Available at: https:/www.fwc.gov.au/about-us/ reports-publications/general-managers-reports (accessed 1 April 2016).

Fair Work Ombudsman (FWO) (2014) Annual Report 2013-14. Melbourne, VIC, Australia: FWO.

Ferguson A, Toft K and Christodoulou M (2016) Money for nothing. Four Corners, 8 March. Available at: http://www.abc.net.au/4corners/stories/2016/03/07/4417757.htm (accessed 1 April 2016).

Freudenberg G (1977) A Certain Grandeur: Gough Whitlam in Politics. Melbourne, VIC, Australia: Viking.

Gahan P (2007) Employer Greenfields Agreements under Work Choices. Melbourne, VIC, Australia: Office of the Workplace Rights Advocate.

Gittins R (2007) Dark art of econometrics. Sydney Morning Herald, 27 August. Available at: http:// www.smh.com.au/news/business/dark-art-of-econometrics/2007/08/26/1188066946510. html (accessed 6 April 2016).

Green R and Toner P (2014) Productivity Commission's myopic failure on industry assistance. The Conversation, 2 July. Available at: http://theconversation.com/productivity-commissions-myopic-failure-on-industry-assistance-28616 (accessed 6 April 2016).

Hannan E (2015) Business pleased with workplace blueprint but PM wary. Australian Financial Review, 4 August. Available at: http://www.afr.com/news/policy/industrial-relations/ business-pleased-with-workplace-blueprint-but-pm-wary-20150804-gir5io-ixzz43yv8kyxa (accessed 8 April 2016).

Hannan E (2016) Australian building and construction commission bill faces senate defeat. Australian Financial Review, 12 March. Available at: http:/www.afr.com/business/ construction/australian-building-and-construction-commission-bill-faces-senate-defeat20150312-142i30 (accessed 12 April 2016).

Hocking J (2012) Gough Whitlam: His Time. Melbourne, VIC, Australia: Miegunyah Press.

Hudson P (2005) All power to Howard. Sunday Age, 7 August, p. 8.

Ivy Worldwide (2016) Why third-party endorsements matter. Available at: http://ivyworldwide. com/services/third-party-endorsement/ (accessed 1 April 2016).

Kenny M and Lucas C (2013) Liberals' ire as Abetz goes 'freelancing'. Sydney Morning Herald, 23 August. Available at: http://www.smh.com.au/federal-politics/federal-election-2013/liberals-ire-as-abetz-goes-freelancing-20130822-2seh8.html (accessed 8 April 2016). 
Liberal Party of Australia and National Party (2013) The coalition's policy to improve the fair work laws. Available at: http://lpaweb-static.s3.amazonaws.com/Policies/FairWork.pdf (accessed 15 April 2016).

Ling S and Waterhouse J (2009) Individual firms and regional business clusters: the HRM advantage in rent generation. Paper presented at Labour, Capital and Change: Proceedings of the 23rd conference of the Association of Industrial Relations Academics of Australia and New Zealand, Newcastle upon Tyne, 4-6 February.

Lloyd CJ and Reid GS (1974) Out of the Wilderness: The Return of Labor. Melbourne, VIC, Australia: Cassell \& Co.

Lynn J and Jay A (2011) The Complete Yes Minister. London: Random House.

Lyons T (2015) There may be non-economic considerations. The Monthly, 5 August. Available at: https://www.themonthly.com.au/blog/tim-lyons/2015/05/2015/1438744398/there-may-benon-economic-considerations (accessed 6 April 2016).

McCallum, Moore M and Edwards J (2012) Towards More Productive and Equitable Workplaces: An Evaluation of the Fair Work Legislation: Report of the Fair Work Act Review. Canberra, ACT, Australia: Department of Education, Employment and Workplace Relations.

McCrystal S (2006) Shifting the balance of power in collective bargaining: Australian law, industrial action and WorkChoices. The Economic and Labour Relations Review 16(2): 9.

Maley J (2007) WorkChoices fear campaign to blame. The Australian, 26 November, p. 8.

Massola J (2014a) Abetz says WorkChoices scare 'neutralised' by Coalition. Sydney Morning Herald, 3 September. Available at: http://www.smh.com.au/federal-politics/political-news/ abetz-says-workchoices-scare-neutralised-by-coalition-20140902-10bgz9.html (accessed 8 April 2016).

Massola J (2014b) Workers under microscope: Abbott government to scrutinise pay, penalties, conditions. Sydney Morning Herald, 7 March. Available at: http://www.smh.com.au/federalpolitics/political-news/workers-under-microscope-abbott-government-to-scrutinise-pay-penalties-conditions-20140306-34aau.html (accessed 6 April 2016).

Morris S (2007) Small swings, vital losses. Australian Financial Review, 26 November, p. 14.

Murray G (2006) Capitalist Networks and Social Power in Australia and New Zealand. Aldershot: Ashgate Publishing.

NSW Business Chamber (2013) Small business: too big to ignore. Available at: http://www.nswbusinesschamber.com.au/Issues/Campaigns/Small-Business-Too-Big-to-Ignore (accessed 9 April 2016).

Peetz D (2002) Sympathy for the devil? Attitudes to Australian unions. Australian Journal of Political Science 37(1): 57-80.

Peetz D (2006) Brave New Workplace: How Individual Contracts Are Changing Our Jobs. Sydney, NSW, Australia: Allen \& Unwin.

Peetz D (2010) Are individualistic attitudes killing collectivism? Transfer: European Review of Labour and Research 16(3): 383-398.

Peetz D and Bailey J (2011) Neoliberal evolution and union responses in Australia. In: Gall G, Wilkinson A and Hurd R (eds) International Handbook on Labour Unions: Responses to Neo-Liberalism. Cheltenham: Edward Elgar, pp. 62-81.

Peetz D and Preston A (2009) Individual contracting, collective bargaining and wages in Australia. Industrial Relations Journal 40(5): 444-461.

Phillips M (2014) Vic election: we are union, hear us roar. Working Life, 1 December. Available at: http://workinglife.org.au/2014/12/01/we-are-union-hear-us-roar/ (accessed 11 April 2016).

Pocock B (2016) Holding up half the sky? Women at work in the 21 st century. The Economic and Labour Relations Review 27(2): 147-163. 
Price J (2015) Anti-penalty rates campaign backfires. Canberra Times, 7 April. Available at: http:// www.canberratimes.com.au/comment/antipenalty-rates-campaign-backfires-20150406-1mfblu (accessed 11 April 2016).

Productivity Commission (PC) (2009) Executive Remuneration in Australia: Productivity Commission Inquiry Report, No 49. Melbourne, VIC, Australia: PC.

Productivity Commission (PC) (2014) Public Infrastructure: Productivity Commission Inquiry Report, vol. 2, no 71. Melbourne, VIC, Australia: PC.

Productivity Commission (PC) (2015a) Workplace Relations Framework Draft Report: Overview. Melbourne, VIC, Australia: PC.

Productivity Commission (PC) (2015b) Workplace Relations Framework: Issues Papers (Nos 1-5). Australian Policy Online, 22 January. Available at: http://apo.org.au/resource/workplace-relations-framework-issues-papers (accessed 12 April 2016).

Productivity Commission (PC) (2015c) Workplace Relations Framework: Productivity Commission Inquiry Report, vol. 1. Canberra, ACT, Australia: PC.

Quiggin J (2015) Effects of Penalty Rates in the Restaurant Sector Brief Prepared for United Voice in Relation to the Fair Work Commission Review of Penalty Rates. Brisbane, QLD, Australia: University of Queensland.

Ransley J (2015) A rocky road for unwary royal commissioners. Inside Story, 31 August. Available at: http://insidestory.org.au/a-rocky-road-for-unwary-royal-commissioners (accessed 15 April 2016).

Roy Morgan Research (2014) Roy Morgan Image of Professions Survey 2014 - Nurses still most highly regarded-followed by Doctors, Pharmacists \& High Court Judges. Roy Morgan Research, 11 April. Available at: http://www.roymorgan.com.au/findings/5531-image-ofprofessions-2014-201404110537

Skinner N and Pocock B (2014) The Persistent Challenge: Living, Working and Caring in Australia in 2014: The Australian Work and Life Index 2014. Adelaide, SA, Australia: Centre for Work + Life; University of South Australia.

Spies-Butcher B and Wilson S (2007) Did Work Choices impact on the NSW election result? Australian Review of Public Affairs Digest, May. Available at: http://www.australianreview. net/digest/2007/05/spies-butcher_wilson.html (accessed 15 April 2016).

Taft P (1998) Does who wins matter more or less? An analysis of major party candidate views on some aspects of economic policy, 1987-1996. Public Policy Program, Discussion paper no. 57. Canberra, ACT, Australia: Australian National University.

Taylor L (2015) Tony Abbott says cutting penalty rates will create jobs, but voters disagree. The Guardian, 23 January. Available at: http://www.theguardian.com/australia-news/2015/ jan/23/coalition-faces-uphill-task-convincing-even-their-supporters-on-penalty-rates (accessed 12 April 2016).

The Australian (2015) Time to bust workplace myths: sweeping IR changes. The Australian, 23 January. Available at: http://www.theaustralian.com.au/national-affairs/industrial-relations/time-to-bust-workplace-myths-sweeping-ir-review/story-fn59noo3-1227193924736 (accessed 8 April 2016).

Tran C (2015) Small businesses and restaurants forced to close over Easter long weekend because they can't afford to pay inflated penalty rates that allow teenagers to earn up to $\$ 50$ an HOUR. Daily Mail, 3 April. Available at: http://www.dailymail.co.uk/news/article-3023232/Smallbusinesses-restaurants-forced-close-Easter-long-weekend-t-afford-pay-inflated-penaltyrates-allow-teenagers-earn-50-HOUR.html-ixzz43vAVJ7zB (accessed 12 April 2016).

Turnbull HM (2016) Interview: Prime Minister Malcolm Turnbull on ABCC legislation, tax reform, negative gearing. $A B C$ 7.30, 21 March. Available at: http://www.abc.net.au/7.30/ content/2015/s4429301.htm (accessed 14 April 2016). 
Verma A (2005) What do unions do to the workplace? Union effects on management and hrm policies. Journal of Labor Research 26(3): 415-449.

Walker E and Burgin K (2015) The astonishing power of 3rd party endorsements. BPlans: Starting a Business Made Easy. Available at: http://articles.bplans.com/the-astonishing-power-of-3rdparty-endorsements/ (accessed 6 February 2016).

Weller P and Cutt J (1976) Treasury Control in Australia. Sydney, NSW, Australia: Ian Novak Publishing.

Westacott J (2015) Creating jobs in the age of disruption. Media and Speeches, Business Council of Australia, 13 August. Available at: http://www.bca.com.au/media/creating-jobs-in-theage-of-disruption-kingsley-laffer-memorial-lecture-by-jennifer-westacott (accessed 15 April 2016).

Yu S (2015) Evaluating the Impact of Sunday Penalty Rates in the NSW Retail Industry Report Prepared for the Shop, Distributive and Allied Employees Association (SDA). Sydney, NSW, Australia: University of Sydney Business School.

\section{Author biography}

David Peetz is a Professor of Employment Relations at Griffith University and a Fellow of the Academy of Social Sciences in Australia. He has consulted for the International Labour Organisation in Thailand, Malaysia, China and Geneva and undertaken work for unions, employers and governments. He is the author of Unions in a Contrary World (1998) and Brave New Workplace (2006), in addition to numerous academic articles, papers and reports. He made a substantial submission to the Productivity Commission's 2015 Inquiry into the Workplace Relations Framework. 